\title{
OCCURRENCE OF AFLATOXINS IN PEANUTS AND PEANUT PRODUCTS CONSUMED IN THE STATE OF SÃO PAULO/BRAZIL FROM 1995 TO 1997
}

\author{
Myrna Sabino, Thais Valéria Milanez*, Leda Conceição Antonia Lamardo, Emiko Ikejiri Inomata, \\ Maria Ângela Pompeu Zorzetto, Sandra Aparecida Navas, Monica Stofer
}

Seção de Química Biológica, Instituto Adolfo Lutz, São Paulo, SP, Brasil

Submitted: February 18, 1998; Returned to authors for corrections: July 21, 1998. Approved: April 04, 1999

\begin{abstract}
One hundred and thirty seven samples of peanuts and peanut containing foods were collected in markets in the State of São Paulo, Brazil, between January 1995 an December 1997. Most of the samples were collected by the Inspection Service of São Paulo Secretary of Health. The foods included raw peanuts, peanut candies ("paçoca" and "pé de moleque"), peanut butter, fried/roasted salted peanuts, "torrone", chocolate coated peanuts and saltcoated peanuts. The samples were analyzed for aflatoxins using a thin-layer chromatographic method. About $45 \%$ of the samples were positive for aflatoxins and $27 \%$ exceeded the limits of the Brazilian legislation $\left(30.0 \mu \mathrm{g} \cdot \mathrm{kg}^{-1}\right.$ for aflatoxins $\left.\mathrm{B}_{1}+\mathrm{G}_{1}\right)$. The aflatoxins were confirmed by derivatization with trifluoroacetic acid. The $90^{\text {th }}$ percentile was 110.0 in $1995,60.0$ in 1996 and $118.0 \mu \mathrm{g} . \mathrm{kg}^{-1}$ in 1997 . The aflatoxins concentration in the raw peanut samples ranged from 5.0 to $382.0 \mu \mathrm{g} \cdot \mathrm{kg}^{-1}$ and $27.1 \%$ were above the legal limits. Contamination in peanut candies was above the limit in $32.8 \%$ of the samples and the aflatoxins levels ranged from 6.0 to $494.0 \mu \mathrm{g} \cdot \mathrm{kg}^{-1}$. Contamination of salty peanuts was less frequent, around $10 \%$ of the samples and the toxin levels were usually below $10 \mu \mathrm{g} \cdot \mathrm{kg}^{-1}$. The maximum level of contamination, $536.0 \mu \mathrm{g} \cdot \mathrm{kg}^{-1}$, was found in a sample of peanut with a salty coat ("amendoim japonês"). Results of previous studies in peanuts and peanut products in the city of São Paulo from 1980-1987 had 68.75\% of the samples with levels greater than the limit $30.0 \mu \mathrm{g} \cdot \mathrm{kg}^{-1}$ and the $90^{\text {th }}$ percentile ranged from 42.0 to $333.0 \mu \mathrm{g} \cdot \mathrm{kg}^{-1}$. In $1994,36.0 \%$ of the samples showed results above the limit and the $90^{\text {th }}$ percentile was $489 \mu \mathrm{g} \cdot \mathrm{kg}^{-1}$. The results show that aflatoxins contamination in peanuts is decreasing but it is still a serious problem in Brazil, a country where the climate, the agricultural practices and storage conditions favour fungal growth.
\end{abstract}

Key words: aflatoxins, peanuts, peanut products, thin-layer chromatography

\section{INTRODUCTION}

Aflatoxins were discovered almost forty years ago and aflatoxin $\mathrm{B}_{1}$ is the most toxic substance of the group. It can cause liver damage, impaired productivity and reproductive efficiency in different animal species (12).

Aflatoxin contamination is the main problem in peanuts and peanut products in Brazil $(2,5,6,8,9,10)$. The World Health Organization recommends a

\footnotetext{
* Corresponding author. Mailing address: Seção de Química Biológica, Instituto Adolfo Lutz, Av. Dr. Arnaldo, 355, CEP 01246-902, São Paulo, SP, Brasil. Fax: (+5511) 853-3505
} 
systematic control of aflatoxin level in the population diet, mainly in countries located in tropical and subtropical areas, where the climatic conditions favour the growth of aflatoxin-producing fungi (13). Given the necessary conditions for mould growth and toxin production, agricultural commodities may be contaminated in the field or after harvest during storage, processing and transport. Once the commodities are contaminated they become not only a public health hazard but also a financial loss (4).

Since 1976 the Brazilian regulatory limit in food is $30.0 \mu \mathrm{g} . \mathrm{kg}^{-1}$ for the sum of the concentrations of aflatoxin $\mathrm{B}_{1}\left(\mathrm{AFB}_{1}\right)$ and aflatoxin $\mathrm{G}_{1}\left(\mathrm{AFG}_{1}\right)$ (1). More recently MERCOSUL, a group for common market among Argentina, Brazil, Paraguay and Uruguay, through the Resolution 56/94, established the maximum limit of $20.0 \mu \mathrm{g} \cdot \mathrm{kg}^{-1}$ for the sum of the aflatoxins $\mathrm{B}_{1}, \mathrm{~B}_{2}, \mathrm{G}_{1}$ and $\mathrm{G}_{2}$. This resolution was already internalized by the Brazilian Ministry of Agriculture (Portaria o 183 of March 21,1996) and the same is expected to happen by the Brazilian Ministry of Health.

The Instituto Adolfo Lutz monitors the levels of aflatoxins in peanuts and peanut products consummed in São Paulo area through a joint program with The Sanitary Guidance of the Secretary of Health of São Paulo State. The present work reports the results from the 1995-1997 inspection. The study aims to collect data in order to furnish the State government adequate information, so it can act accordingly.

\section{MATERIALS AND METHODS}

One hundred and thirty seven samples of raw peanuts and peanut containing foods, collected from January 1995 to December 1997 in São Paulo markets, were inclued in this study.

About $3.0 \mathrm{~kg}$ of sample of the lot under inspection were collected and divided into three $1 \mathrm{~kg}$ sub-samples designated 1,2 and 3. One of them was finely ground in a blender (Waring - Model 31BL.91) and homogenized. A sub-sample of $50 \mathrm{~g}$ was taken for the aflatoxins determination.

Aflatoxins $B_{1}$ and $G_{1}$ were determined by thin-layer chromatography (TLC), according to the method described by Soares and Rodriguez-Amaya (11). It involved extraction with a mixture of methanol and $4 \% \mathrm{KCl}(9+1, \mathrm{v} / \mathrm{v})$, followed by a clarification step with $10 \% \mathrm{CuSO}_{4}$ and partition to chloroform. The limit of quantification obtained was $5.0 \mu \mathrm{g} . \mathrm{kg}^{-1}$. The chemical confirmation of $\mathrm{AFB}_{1}$ and $\mathrm{AFG}_{1}$ was performed with trifluoroacetic acid (7).

\section{RESULTS AND DISCUSSION}

From 137 samples, $45.3 \%$ (62 samples) were positive for aflatoxins and $27.0 \%$ (37 samples) presented levels of $\mathrm{AFB}_{1}+\mathrm{AFG}_{1}$ above the maximum limit allowed by the Brazilian Legislation $\left(30.0 \mu \mathrm{g} \cdot \mathrm{kg}^{-1}\right)$ (Tables 1 and 2). The $90^{\text {th }}$ percentile was $110.0 \mu \mathrm{g} \cdot \mathrm{kg}^{-1}$ in 1995, $60.0 \mu \mathrm{g} \cdot \mathrm{kg}^{-1}$ in 1996 and $118.0 \mu \mathrm{g} \cdot \mathrm{kg}^{-1}$ in 1997 (Table 1). Comparing these values with the results obtained in the 1980-1987 study (9), which ranged from 42.0 to $333.0 \mu \mathrm{g} . \mathrm{kg}^{-1}$, the present results were lower but still of concern. In the present study the aflatoxins concentration in the raw peanuts samples ranged from 5.0 to $382.0 \mu \mathrm{g} . \mathrm{kg}^{-1}$ and $27.1 \%$ were above the regulatory limits while $32.8 \%$ of the peanuts candies samples were above the limit and the concentration of aflatoxins $\mathrm{B}_{1}+\mathrm{G}_{1}$ ranged from 6.0 to $494.0 \mu \mathrm{g} . \mathrm{kg}^{-1}$. Contamination in salted peanuts samples were around $10.0 \%$. The toxins concentrations were mostly below $10.0 \mu \mathrm{g} . \mathrm{kg}^{-1}$ except for one sample of salt coated peanut ("amendoim japonês") that presented a level of $536.0 \mu \mathrm{g} . \mathrm{kg}^{-1}$.

Table 1. Levels of $\mathrm{AFB}_{1}$ and $\mathrm{AFG}_{1}$ in samples of peanuts and peanut containing foods ( $\left.\mu \mathrm{g} . \mathrm{kg}^{-1}\right)$

\begin{tabular}{ccccccc}
\hline Year & $\mathrm{n}^{\mathrm{o}}$. of samples & $>30 \mu \mathrm{g} . \mathrm{kg}^{-1}$ & $\begin{array}{c}<30 \mu \mathrm{g} . \mathrm{kg}^{-1} \\
>5 \mu \mathrm{g} . \mathrm{kg}^{-1}\end{array}$ & median & $\begin{array}{c}90^{\text {th }} \\
\text { percentile }\end{array}$ & $\begin{array}{c}\text { maximum } \\
\text { level }\left(\mu \mathrm{g} . \mathrm{kg}^{-1}\right)\end{array}$ \\
\hline 1995 & 58 & $18(31.0 \%)$ & $10(17.3 \%)$ & $<5$ & 110 & $494^{\mathrm{a}}$ \\
1996 & 50 & $09(18.0 \%)$ & $08(16.0 \%)$ & $<5$ & 60 & $469^{\text {a }}$ \\
1997 & 29 & $10(34.5 \%)$ & $07(24.1 \%)$ & $<5$ & 118 & $536^{\mathrm{b}}$ \\
\hline TOTAL & 137 & $37(27.0 \%)$ & $25(18.3 \%)$ & $<5$ & 123 & 536 \\
\hline
\end{tabular}

a - sample of candy made with peanut ("paçoca")

b - sample of peanut with salty cover ("amendoim japonês") 
Table 2. Distribution of aflatoxins $B_{1}$ and $G_{1}$ in peanuts and peanut containing food samples according to the present Brazilian legislation (\%).

\begin{tabular}{|c|c|c|c|c|c|c|}
\hline \multirow[t]{3}{*}{ year } & \multirow{2}{*}{\multicolumn{2}{|c|}{$\begin{array}{l}\text { raw peanut } \\
\text { unshelled }\end{array}$}} & \multicolumn{4}{|c|}{ peanut containing food } \\
\hline & & & \multicolumn{2}{|c|}{ candies } & \multicolumn{2}{|c|}{ salted } \\
\hline & App. & Cond. & App. & Cond. & App. & Cond. \\
\hline 1995 & 68.7 & 31.3 & 60.6 & 39.4 & 100.0 & 0.0 \\
\hline 1996 & 89.5 & 10.5 & 72.7 & 27.3 & 88.9 & 11.1 \\
\hline 1997 & 53.8 & 46.2 & 75.0 & 25.0 & 75.0 & 25.0 \\
\hline TOTAL & 72.9 & 27.1 & 67.2 & 32.8 & 90.9 & 9.1 \\
\hline
\end{tabular}

App. Aproved

Cond. Condemned

Sabino (8) analyzed 572 samples of food products including peanuts in the period 1971 to 1975 and reported higher levels such as $7,800 \mu \mathrm{g} . \mathrm{kg}^{-1}$ and a mean of $1131.0 \mu \mathrm{g} \cdot \mathrm{kg}^{-1}$. In the $1980-1982$ period, Scussel and Rodriguez-Amaya (10) analyzed 241 samples of peanuts and peanut products. They found 128 to be positive, of which 92 exceeded the maximum limit of $30.0 \mu \mathrm{g} \cdot \mathrm{kg}^{-1}$. Sabino et al. (9) analyzed 1,374 samples during the period 1980-1987 and found $68.7 \%$ of the samples of peanuts and its products with concentrations of aflatoxins $B_{1}+G_{1}$ greater than the limit allowed. Prado et al. (6) analyzed 400 samples of rawpeanuts consumed in Belo Horizonte (MGBrazil), $61.5 \%$ were positive ranging from 4 to 1032 $\mu \mathrm{g} \cdot \mathrm{kg}^{-1}$ of $\mathrm{AFB}_{1}$. Oliveira et al. (5) found aflatoxins $\mathrm{B}_{1}$ and $G_{1}$ above the maximum limit in $34.6 \%$ of 104 samples of peanuts collected in retail stores of Goiania/GO, Brazil. Brigido et al. (2) found $47 \%$ of 96 samples of peanuts and products from Campinas to exceed the maximum limit. All these studies detected a very high percentage of contaminated peanut samples. Specially of concern are candies made with peanuts ("paçoca" and "pé-de-moleque") because they are consummed basically by youngsters. Frequently these products are sold inside or nearby schools. According to the present regulations $\left(\mathrm{B}_{1}+\right.$ $\mathrm{G}_{1}=30.0 \mu \mathrm{g} \cdot \mathrm{kg}^{-1}$ ) about $30 \%$ of the samples of candies with peanuts were found to be over the limit, this percentage rises to about $50 \%$ if the MERCOSUL limits are considered. The Codex Alimentarius Commission (3) has recommended a level on 5.0 $\mu \mathrm{g} . \mathrm{kg}^{-1}$ for aflatoxin in food. In the present survey, $45 \%$ of the samples were found to be contaminated with $\mathrm{AFB}_{1}$ and $\mathrm{AFG}_{1}$ exceeding this recommended level, whereas only $27 \%$ of the samples exceeded the present Brazilian tolerance limit. Probably when the MERCOSUL limits $\left(20.0 \mu \mathrm{g} . \mathrm{kg}^{-1}\right.$ for the sum of aflatoxins $B_{1}, B_{2}, G_{1}$ and $G_{2}$ ) is internalized by the Health Ministry the percentage of condemned samples will be higher.

Suggestions to change the present situation may include: a) motivation of agriculture extension services to educate farmers on the problems of mycotoxins and to encourage farmers to use good agricultural practices in order to minimize field, harvest and post-harvest contamination; b) increasing government awareness of its responsibilities concerning the marketing and comsuption of peanut and peanut products.

\section{RESUMO}

\section{Ocorrência de aflatoxinas em amendoim e produtos contendo amendoim consumidos no Estado de São Paulo/ Brasil no período 1995-1997}

Cento e trinta e sete amostras de amendoim e produtos contendo amendoim, obtidas no período de janeiro de 1995 a dezembro de 1997, a grande parte delas coletadas pela Vigilância Sanitária da Secretaria de Saúde do Estado de São Paulo, foram submetidas à determinação de aflatoxinas. Foram incluídas amostras de amendoins cru, doces de amendoim ("paçoca" e "pé-de-moleque"), pasta de amendoim, amendoins salgados (frito e torrado), "torrone" e amendoins com cobertura de chocolate ou cobertura salgada ("amendoim japonês"). As amostras foram analisadas por cromatografia em camada delgada.

Sessenta e duas amostras $(45,3 \%)$ foram positivas para aflatoxinas e 37 amostras $(27,0 \%)$ apresentaram valores de aflatoxinas $B_{1}+G_{1}$ acima do limite máximo da legislação brasileira $\left(30,0 \mu \mathrm{g}\right.$. $\mathrm{kg}^{-1}$ para aflatoxinas $\mathrm{B}_{1}+\mathrm{G}_{1}$ ). A identidade destas aflatoxinas foi confirmada usando-se ácido trifluoro acético. $\mathrm{O} 90^{\text {th }}$ percentil foi 110,0 em 1995, 60,0 em 1996 e 118,0 $\mu \mathrm{g} . \mathrm{kg}^{-1} \mathrm{em}$ 1997. A concentração de aflatoxinas nas amostras de amendoim cru variou de 5,0 a $356,0 \mu \mathrm{g} \cdot \mathrm{kg}^{-1}$ e $27,1 \%$ delas acima do limite. Quanto à contaminação por aflatoxinas nas amostras de doces de amendoim $32,8 \%$ delas estavam acima do limite e as concentrações variaram de 6,0 a $536,0 \mu \mathrm{g}$. $\mathrm{kg}^{-1}$. A contaminação nos amendoins salgados foi menos frequente, cerca de $10 \%$ das amostras e os níveis de toxina geralmente abaixo de $10,0 \mu \mathrm{g} . \mathrm{kg}^{-1}$, porém uma das amostras com cobertura ("amendoim japonês") apresentou 536,0 $\mu \mathrm{g} . \mathrm{kg}^{-1}$. Comparando com os dados 
de incidência de 1980-1987 em amendoim e produtos de amendoim na cidade de São Paulo, quando 68,75\% das amostras mostraram valores maiores que o limite permitido e o $90^{\text {th }}$ percentil variou de 42,0 a 333,0 $\mu \mathrm{g} . \mathrm{kg}^{-1}$, e de 1994 quando $36,0 \%$ das amostras mostraram resultados acima do limite e o $90^{\text {th }}$ percentil foi $489,0 \mu \mathrm{g} \cdot \mathrm{kg}^{-1}$, os resultados deste trabalho mostram que a contaminação por aflatoxinas está diminuindo. Entretanto, mostram também que a contaminação por aflatoxinas em amendoim continua um problema sério no Brasil mas que deve-se levar em conta não somente as condições climáticas (umidade e altas temperaturas) mas também as práticas de agricultura e as condições de estocagem.

Palavras-chave: aflatoxinas, amendoim, produtos contendo amendoim, cromatografia em camada delgada

\section{REFERENCES}

1. Brasil, Leis, Decretos,etc.,1977: Resolução no 34/76. Diário Oficial, Rio de Janeiro, Seção 1, pt. 1/10. Fixa padrões de tolerância para as aflatoxinas em alimentos. January $19^{\text {th }}$.

2. Brígido, B.M.; Badolato, M.I.C.; Freitas, V.P.S. Contaminação de amendoim e seus produtos comercializados na região de Campinas-SP, por aflatoxinas durante o ano de 1994. Rev. Inst.Adolfo Lutz,55: 85-90, 1995.
3. Codex Alimentarius Commission. Report on the twentieth session of the Codex Commitee on Food Additives and Contaminants..Alinorm 89/2. (Rome: Food and Agriculture organization), p. 16.

4. Miller, J.D. Fungi and mycotoxin in grain: implications for stored product research. J. Stored Prod. Res., 31(1): 1-16, 1995.

5. Oliveira, V.; Mesquita, A.J.; Serafini, A.B.; Ribeiro, J.L.; Silva, M.R.R. - Ocorrência de aflatoxinas $B_{1}$ e $G_{1}$ em amendoim comercializado em Goiânia - GO, Brasil. Rev. Microbiol., 22: 319322, 1991.

6. Prado, G.; Mattos, S.V.M.; Pereira, E.C. - Níveis de aflatoxinas em alguns alimentos consumidos em Belo Horizonte no período de 1983 a 1988. Ciênc. Tecnol. Alim., 9: 138-147, 1989.

7. Przybylski, W. Formation of aflatoxin derivatives on thin layer chromatographic plates. J.Assoc.Off.Anal.Chem.,58: 163-164, 1975.

8. Sabino, M. Variações de níveis de aflatoxina $\mathrm{B}_{1}$ em alimentos e rações animais no período de 1971 a 1979. Rev. Inst. Adolfo Lutz, 4: 153-158, 1980.

9. Sabino, M., Zorzetto, M.A.P., Pedroso, M.O., Milanez, T.V. Incidência de aflatoxinas em amendoim e produtos derivados consumidos na cidade de São Paulo, no período de 1980 a 1987. Rev. Inst. Adolfo Lutz, 49: 41-44, 1989.

10. Scussel,V.M. ; Rodriguez-Amaya, D.B. Teores de aflatoxinas em amendoim e seus produtos comercializados em Campinas em 1980-82. Boletim da SBCTA, 19: 109-119, 1985.

11. Soares, L.V.; Rodriguez-Amaya, D.B. Survey of aflatoxins, ochratoxin A, zearalenone and sterigmatocystin in some Brazilian foods using a multi-toxin thin-layer chromatographic method. J.Assoc.Off. Anal.Chem., 72: 22-26, 1989.

12. World Health Organization, 1979, Guidelines for establishing or strengthening National Food Contamination Monitoring Programmes, FAO FOOD Control Series no 5 (Geneve: WHO).

13. World Health Organization. Environmental Health Criteria. 11. Mycotoxins. (Geneva: WHO), 1979, p.127. 